\title{
Transfer Of Functions Of Agriculture To Non Agriculture Land Under Government Regulation Number 1 Of 2011 Concerning The Establishment And Transfer Function Of Agricultural Land Sustainable The Food
}

\author{
Indana Fawaizah ${ }^{1}$, Arif Zaenal Abidin² and Anis Mashdurohatun ${ }^{3}$
}

\begin{abstract}
In this study concluded that: Implementation of agricultural land conversion to non agriculture through several stages, namely: a. The applicant submits the application permit conversion of land attached with the above requirements. b. Setting and Planning Section of Land examination whose results land noted in the minutes of technical considerations arrangement of land. c. The committee did Meetings Land examination, the results are set forth in the Minutes for consideration demolition permit over the land / Land Use Change Permit (IPPT) by the Head of the Land Office. d. Issuance of land conversion permits Decree (SK Land Use Change Permit). e. Delivery of the Decree of the land conversion permit (SK Land Use Change Permit). Act No.41 of 2009 on the Protection of Agricultural Land Sustainable Food, Government Regulation No. 1 of 2011 on the Establishment and Transfer Function Agricultural Land Sustainable Food has been able to balance the food sector while Act No. 26 of 2007 on Spatial Planning, has not fully balance the conversion of agricultural land to non-agricultural because there is a review of every five (years) 1 (one time. Implementation of the transformation of agricultural land to non-agricultural constrained because some of the following: a. Refusal of requests for land use only verbally. b. The term of service of technical considerations of land is 13 (thirteen) days. But in practice it can reach 3 months. c. The calculation of the cost of land use not in accordance with the applicable regulation.

Keywords: Judicial Review; Over the function of Land; Agriculture and NonAgriculture Land.
\end{abstract}

\section{Introduction}

Land as part of the Earth that is the gift of God Almighty serve to meet basic human needs. In the development of land has also become a lucrative investment tool, resulting in increased demand for land and buildings, and also the competition to acquire it, which in turn forces people to issue a greater sacrifice to get it. This leads to the land and the building to be very valuable, so that people who own land and

\footnotetext{
1 Master of Notary's Student, Faculty of Law, Universitas Islam Sultan Agung email indana1988@gmail.com.

2 Students of Master of Law, Faculty of Law, Universitas Islam Sultan Agung email arif.reaz808@gmail.com

${ }^{3}$ Head of Doctoral Program of the Faculty of Law UNISSULA Semarang Indonesia.
} 
buildings will be wherever possible to maintain ownership of the land ${ }^{4}$.

To guarantee legal certainty in the field of land, then article 19 paragraph (1) BAL is determined "to ensure legal certainty by government held land registration throughout the territory of the Republic of Indonesia in accordance with the regulations stipulated by government regulations"5.

Transfer Function Agricultural Land Sustainable Food is Agricultural Land use change is becoming Sustainable Food not either permanently or temporarily.

Based on Government Regulation No. 1 In 2011, Article 35 stated that land has been designated as Agricultural Land Sustainable Food protected and converted prohibited. The transformation of Agricultural Land Sustainable Food can only be done by the Government or local governments in order to: Procurement of land for public purposes, the disaster occurred.

In Government Regulation No. 1 In 2011, Article 36 stated that the Transfer Function of Agricultural Land Sustainable Food conducted within the framework of land acquisition for public purposes is limited to the public interest, which includes: Public roads, reservoirs, Dams, Irrigation Channels drinking water or clean water, drainage and sanitation, building irrigation, Ports, Airports, stations and railway tracks, terminals, public safety facilities, the nature reserve and / or, plant and electricity networks.

Conversion of agricultural land sustainable food in order to procure land for the public interest can only be done with the requirements (Article 30), namely: Has feasibility study strategic Having a plan land use, acquisition of ownership rights to land, availability of replacement land to the Agricultural Land Sustainable Food that converted.

In the Act and Regulation are above it can be seen that the government gives great attention to the wetland, where in addition to Act and Regulation that lays out about the importance of wetland for national food security, the Government gives serious attention to farmers land owners, in order to minimize conversion agricultural land. But the lack of traction in the application of the field, making the Act and Regulation that there is not a big impact, farmers still functioned transfer my land.

Rapid population growth followed by making the housing needs of agricultural lands is reduced in many regions. Land of the narrow increasingly fragmented due to the need for housing and industrial estates. Farmers prefer to work in the informal sector rather than persist in the agricultural sector. The attractiveness of the agricultural sector continues to decline also makes farmers tend to be followed by the land conversion. ${ }^{6}$ Recorded in Tegal regency has an area of agricultural land in 2016 covering an area of 50696 hectares. Every year shrank 2 hectares of productive agricultural land in Tegal regency lost, due to the conversion or the conversion of agricultural land. The biggest transfer function caused by the construction of residential or residential complex done

\footnotetext{
4 Pahala Marihot Siahaan 2003 Bea Perolehan Hak atas Tanah dan Bangunan Raja Grafindo Persada.Jakarta p. 32.

${ }^{5}$ Boedi Harsono 1988 Hukum Agraria Indonesia Himpunan Peraturan-peraturan Tanah Jakarta: Bridge $\mathrm{p} 11$.

${ }^{6}$ Gunanto 2007 ES Konversi Lahan Pertanian Mengkhawatirkan. PT. Raja Persindo Persada p 35
} 
by the developers or the creation of plots of land ready to build, even some that are used for the mining industry.

Provincial Legislative Council (DPRD) Tegal then issued Regional Regulation No. 10 of 2012 on Spatial Planning (RTRW) of 2012-2032, in which the regulation was aimed to reduce land conversion activities in Tegal regency. In Article 31, written on agricultural land area of wetlands and dry land. The number of wetlands in Tegal area of 35.949 hectares and the dry land area of 6,630 hectares. ${ }^{7}$

Fundamental to the reality of the case to be examined and the materials of the existing literature, according to the author is interested in conducting research in the title: "Transfer Of Functions Of Agriculture To Non Agriculture Land Under Government Regulation Number 1 Of 2011 Concerning The Establishment And Transfer Function Of Agricultural Land Sustainable The Food."

\section{Research Methods}

The approach used in this study is primarily empirical juridical approach. Juridical empirically identify and conceptualize law as a social institution that is real and functional in living systems are patterned. ${ }^{8}$ Juridical approach in this study is the approach in terms of legislation and legal norms in accordance with the existing problems, whereas the empirical approach is emphasizing research aimed at obtaining empirical knowledge to the road go directly to the object.

\section{Discussion}

\subsection{Implementation of the Agricultural Land Transfer Function Into Non- Agricultural Based on Government Regulation No. 1 of 2011 Concerning Determination of Agricultural Land Transfer Function and Sustainable Food.}

Implementation of the conversion of agricultural land to non-agricultural begins with: 1. Request letters of recommendation Appropriation Permit system space (IPR) to the Bappeda office with the following requirements: Copy of ID owner of the certificate, copy of the certificate, the UN SPPT, and a site plan, 2. After receiving a letter of recommendation from the Department Bappeda IPR, came to the Land Office with the filing of the petition for Technical considerations land which contain the terms and conditions of use and utilization of land, provided that: Copy of ID, copy KK, First Certificate, Copy SPPT UN, 3. Pay the Tax State Revenue (non-tax), 4. Request Permit Recommendation to the Office Agriculture and complete the application form with the requisite review of the location: Technical Considerations copy, copy of ID card, photocopy KK, SPPT UN Appropriation Permit system space (IPR), $5 .{ }^{9}$ The management

\footnotetext{
7 Tegal Regency Regulation No. 10 of 2012 to 2032 on the amendment Spatial Tegal

8 Soerjono Soekanto 1984 Pengantar Penelitian Hukum Jakarta: Indonesian University Press p 51.

${ }^{9}$ Laely Personal Interview Employee Notaris-PPAT Tegal (June 2 2018)
} 
of the issuance of land technical considerations contained in Annex II of the National Land Agency Regulation No. 2 of 2011 on Guidelines for Land Technical Considerations in Publishing License Location, Location Determination and Change of Use Permit. As for the request to change the use of land set out in Annex II to Regulation National Land Agency Number 1 of 2010 on Service Standards and Regulations of the Land.

The conversion of land use in the past may be due to changes in the spatial plan, their wisdom and the development direction for the market mechanism. Development policy that emphasizes the aspects of amenity growth through investment, both to local and overseas investors in the provision of land, the conversion of farmland to nonagricultural widespread. ${ }^{10}$

\subsection{Obstacles in Implementing the Agricultural Land Transfer Function Into Non-Agricultural Based on Government Regulation No. 1 of 2011 Concerning Determination and Transfer Function Sustainable Food And Agricultural Land solution.}

Implementation of the transformation of agricultural land to non-agricultural constrained by specific causes for some of the following things: a. Refusal of requests for land use only verbally. This refusal is given by the Head of Sub. Setting and Planning Section Land after checking the status of the land being applied, b. The term of service of technical considerations of land is 13 (thirteen) days. But in practice it can reach 3 months. ${ }^{11}$ This happens because in the process of meeting these considerations involve various agencies related to schedule and obtain signatures from the relevant Head of Department, c. Community participation in the spatial planning process is still very limited. In the process of community planning can not optimal voice an opinion. In the socialization of planning the use of space, the community only an understanding of the positive impact such as the price of land is expensive, the area will be developed, while the negative impact on agricultural land less socialized, $d$. Calculation of the cost required for land conversion has clearly and in accordance with Government Regulation Number 128 of 2015 regarding Type and Tariff for Non Tax Revenue Applicable in the National Land Agency, namely in Article 14 paragraph (3). But in fact appear surcharge voluntary, e. There are no strict sanctions for offenders who violate land conversion for Spatial plan is dynamic so that it can be evaluated.

\section{Closing}

\subsection{Conclusion}

Based on the research results can be concluded as follows:

- Implementation of agricultural land conversion to non agriculture through several stages, namely: a. The applicant submits application permit conversion of land

\footnotetext{
${ }^{10}$ Suwito Personal Interview Head of Sub. Setting and Planning Section of the District Land Office Land Tegal (June 2 2018)

${ }^{11}$ Laely Personal Interview Employee Notary PPAT Tegal (June 2 2018)
} 
attached with the above requirements. b. Setting and Planning Section of Land examination whose results land noted in the minutes of technical considerations arrangement of land. c. The committee did Meetings Land examination, the results are set forth in the Minutes for consideration demolition permit over the land / Land Use Change Permit (IPPT) by the Head of the Land Office. d. Issuance of land conversion permits Decree (SK Land Use Change Permit). e. Delivery of the Decree of the land conversion permit (Permit SK Land Use Change)

- Implementation of the transformation of agricultural land to non-agricultural constrained because some of the following: a. Refusal of requests for land use only verbally, b. The term of service of technical considerations of land is 13 (thirteen) days. But in practice it can reach 3 months, c. The calculation of the cost of land use not in accordance with the applicable regulation, e. There are no strict sanctions for offenders who violate land conversion for Spatial plan is dynamic so that it can be evaluated.

\subsection{Suggestion}

- Keep their awareness of the importance of good Land penataagunaan of the citizens and the government to abide by laws and regulations to maintain, control, and protect agricultural land in order to control Functions agriculture to nonagricultural land does not continue to happen.

- Development does not only aim to boost economic growth, but the food should be preferred because it involves the right of all people so that agricultural land to achieve aspects must maintain a balance and harmony between the public interest with the interests of the individual. The provisions in Article 33, paragraph 3 of the Law of 1945 that the earth, water and natural resources contained therein shall be used for the welfare of the people, to make the law become a tool to achieve justice according to Rawls. The use of the land along with the setting and under the leadership of the country should be used as much as possible for the prosperity of the people.

\section{References}

[1] Pahala Marihot Siahaan, 2003, Bea Perolehan Hak atas Tanah dan Bangunan, Raja Grafindo Persada.Jakarta.

[2] Boedi Harsono, 1988, Hukum Agraria Indonesia, Himpunan Peraturan-peraturan Tanah, Jakarta: Bridge.

[3] Gunanto, 2007, ES, Konversi Lahan Pertanian Mengkhawatirkan. PT. Raja Persindo Persada.

[4] Soerjono Soekanto, 1984, Pengantar Penelitian Hukum, Jakarta: Indonesian University Press.

[5] Laely, Personal Interview, Employee Notaris-PPAT Tegal (June 2, 2018)

[6] Suwito, Personal Interview, Head of Sub. Setting and Planning Section of the District Land Office Land Tegal (June 2, 2018) 
[7] Laely, Personal Interview, Employee Notary PPAT Tegal, (June 2, 2018)

[8] Act No.5 of 1960 on Basic Regulation of Agrarian.

[9] Regulation of the Minister of Agriculture No. 3 of 1997 on provisions for the implementation of Government Regulation No. 24 of 1997

[10] Act No.41 of 2009 on the Protection of Agricultural Land Sustainable Food

[11] Government Regulation No. 1 of 2011 regarding the Agricultural Land Transfer Function and Sustainable Food

[12] Regional Regulation No. 10 of 2012 on Spatial Planning (RTRW) of 2012-2032

[13] Government Regulation Number 128 of 2015 regarding Type and Tariff for Non Tax Revenue Applicable in the National Land Agency

[14] National Land Agency Regulation No. 2 of 2011 on Guidelines for Land Technical Considerations in Publishing License Location, Location Determination and Change of Use Permit.

[15] National Land Agency Regulation No. 1 of 2010 on Service Standards and Regulations of the Land. 